\title{
The association of serum magnesium with serum triglyceride and cholesterol levels in hemodialysis patients
}

\author{
Milad Fooladgar $^{\circledR}$, Saied Mardani $^{1^{*}}{ }^{\circledR}$, Leyla Hedayati Zafarghandi ${ }^{\circledR}$ \\ ${ }^{1}$ Department of Internal Medicine, Faculty of Medicine, Shahrekord University of Medical Sciences, Shahrekord, Iran \\ ${ }^{2}$ Department of Internal Medicine, Faculty of Medicine, Tehran University of Medical Sciences, Tehran, Iran
}

\section{AR T I C L E I N F O}

Article Type:

Original

\section{Article History:}

Received: 5 August 2019

Accepted: 19 September 2019

Published online: 1 November 2019

Keywords:

Lipid

Magnesium

Hemodialysis

\begin{abstract}
A B S T R A C T
Introduction: Dysregulated lipid profile has been described in patients with chronic renal failure. Objectives: In the present study, we investigated the association of serum magnesium level with serum triglyceride and cholesterol levels in a group of hemodialysis individuals.

Patients and Methods: This cross-sectional study was carried out on hemodialysis patients referred to the Hajar hospital of Shahrekord (2015). Patients who have been on hemodialysis for at least three months and had a stable condition for the last two months were recruited. Serum levels of magnesium, cholesterol, and triglyceride were measured, and the data was analyzed.

Results: Of 52 patients, $61.5 \%$ were males. The mean age of the patients was $60.17 \pm 48.70$ (range; 13-78) years and the mean dialysis duration was $44.39 \pm 05.52$ months. Serum magnesium was inversely and insignificantly correlated with serum cholesterol and triglyceride levels. Serum magnesium was significantly associated with serum albumin and parathormone.

Conclusion: We found non-significant and inverse correlations of serum magnesium with serum cholesterol and triglyceride levels. The association between serum magnesium and dyslipidemia is contradictory, and further studies are required to divulge the role of other contributing factors.
\end{abstract}

Implication for health policy/practice/research/medical education:

In an investigation on 52 hemodialysis individuals, we found, non-significant and inverse correlations of serum magnesium with serum cholesterol and triglyceride levels. The association between serum magnesium and dyslipidemia is contradictory, and further studies are required to divulge the role of other contributing factors.

Please cite this paper as: Fooladgar M, Mardani S, Hedayati Zafarghandi L. The association of serum magnesium with serum triglyceride and cholesterol levels in hemodialysis patients. J Nephropharmacol. 2020;9(2):e18. DOI: 10.34172/npj.2020.18.

\section{Introduction}

The mortality rate due to cardiovascular diseases is 20 to 40 times higher in dialysis patients than the general population $(1,2)$. Dysregulated lipid profile has been described in patients with chronic renal failure $(3,4)$. Hypertriglyceridemia occurs in $50-75 \%$ of patients with chronic renal failure. Although hypercholesterolemia is rare in patients with uremia and those undergoing dialysis, the decreased level of high-density lipoprotein (HDL) cholesterol has been reported in these patients $(5,6)$. Magnesium retention is also a common problem in patients under hemodialysis. Several epidemiologic studies have reported an association between low serum magnesium level and the risk of ischemic heart diseases such as coronary artery disease and arteriosclerosis, as well as mortality in hemodialysis patients (7-9). According to the study by Robles et al, magnesium deficiency has been associated with perturbed lipid metabolism affecting several lipid parameters in both non-uremic and uremic patients (6). A relationship has been suggested between serum magnesium and risk factors of ischemic heart diseases such as lipid parameters, diabetes, and serum albumin, phosphorus, and parathormone in hemodialysis patients (2). Nevertheless, there is few published data on the association of serum magnesium and these parameters in hemodialysis patients in Iran.

\section{Objectives}

The aim of this study was to examine the association between serum magnesium level and lipid (i.e. serum triglyceride and cholesterol levels) and other biochemical parameters in Iranian hemodialysis individuals. 


\section{Patients and Methods}

\section{Study design}

This cross-sectional investigation was carried out on 52 individuals referring to the hemodialysis section of Hajar hospital in Shahrekord (2015). Patients who were under regular dialysis for at least three months and had a stable condition for the last two months were recruited. Patients with severe infections, malignancy and history of parathyroidectomy were excluded. Blood samples were collected from all the patients and transferred to the hospital laboratory. Serum levels of magnesium, cholesterol and triglyceride were measured using photometry method. The duration of dialysis was also recorded for all the patients.

\section{Ethical issues}

The research followed the tenets of the Declaration of Helsinki. Written informed consent was obtained from all the patients. This study was approved by the Ethics Committee of Shahrekord University of Medical Sciences (Ethical code \# IR.SKUMS.REC.1394.192).

\section{Statistical analysis}

The results were presented as means \pm SD. Descriptive statistics, Pearson's correlation coefficient, and regression analysis were applied to analyze the data. Accordingly, $P$ value $<0.05$ was considered as the statistical significance level.

\section{Results}

\section{Patients' characteristics}

Of 52 patients, $61.5 \%$ were males. The mean age of the patients was $60.17 \pm 48.70$ (range; $13-78$ ) years and the mean duration of dialysis was $44.39 \pm 05.52$ months (Table 1).

\section{Biochemical Parameters}

The levels of the biochemical parameters assessed in hemodialysis patients have been shown in Table 2 .

\section{Association between serum magnesium level and other} biochemical factors

As shown in Table 3, the inverse and insignificant correlations of serum magnesium with serum cholesterol and triglyceride levels were observed. The associations between serum magnesium, cholesterol, triglyceride, and other biochemical factors have been shown in Table 4 .

\section{Discussion}

Mortality rates due to cardiovascular diseases are 20 to 40 times higher in dialysis patients than the general population (1,2,10-12). In several studies, dysregulated serum lipid parameters including triglyceride and cholesterol, as well as serum magnesium levels have been associated with the pathogenesis of cardiovascular diseases. In the present study, the association of serum magnesium with serum
Table 1. The spectrum of age and hemodialysis duration in the studied patients

\begin{tabular}{lcccc}
\hline & No. & Minimum & Maximum & Means \pm SD \\
\hline Age (y) & 52 & 13 & 87 & $60.17 \pm 48.70$ \\
Dialysis duration (mon) & 52 & 4 & 193 & $44.39 \pm 05.52$ \\
\hline
\end{tabular}

Table 2. Biochemical parameters measured in hemodialysis patients

\begin{tabular}{|c|c|c|}
\hline & No. & Mean \pm SD \\
\hline Magnesium (mg/dL) & 52 & $2.2 \pm 0.2$ \\
\hline Cholesterol (mg/dL) & 52 & $130.42 \pm 42.55$ \\
\hline Triglyceride (mg/dL) & 52 & $98.82 \pm 65.70$ \\
\hline Serum calcium (mg/dL) & 52 & $9.1 \pm 0.53$ \\
\hline Serum albumin (g/dL) & 51 & $4.1 \pm 0.36$ \\
\hline Bicarbonate (mEq/L) & 52 & $21.1 \pm 2.8$ \\
\hline Alkaline phosphatase (U/L) & 52 & $266.2 \pm 120.5$ \\
\hline Serum phosphorus (mg/dL) & 51 & $5.3 \pm 1.1$ \\
\hline Parathyroid hormone $(\mathrm{pg} / \mathrm{mL})$ & 52 & $360.1 \pm 238.2$ \\
\hline $\operatorname{URR}^{\mathrm{a}}(\%)$ & 52 & $0.61 \pm 0.16$ \\
\hline Vitamin D (ng/dL) & 51 & $14.4 \pm 5.5$ \\
\hline Dialysis duration (month) & 52 & $44 \pm 39.5$ \\
\hline Dialysis dose ${ }^{b}$ & 52 & $517.9 \pm 479.4$ \\
\hline
\end{tabular}

Table 3. The association of serum magnesium with lipid parameters in hemodialysis patients

\begin{tabular}{lccc}
\hline & $\begin{array}{c}\text { Magnesium } \\
(\mathrm{mEq} / \mathrm{L})\end{array}$ & $\begin{array}{c}\text { Cholesterol } \\
(\mathrm{mg} / \mathrm{dL})\end{array}$ & $\begin{array}{c}\text { Triglyceride } \\
(\mathrm{mg} / \mathrm{dL})\end{array}$ \\
\hline Magnesium (mEq/L) & $1.00^{\mathrm{a}}$ & -0.13 & -0.03 \\
& $(-)$ & $(0.3)$ & $(0.8)$ \\
Cholesterol (mg/dL) & -0.13 & 1.00 & 0.24 \\
& $(0.3)$ & $(-)$ & $(0.08)$ \\
Triglyceride (mg/dL) & -0.03 & 0.24 & 1.00 \\
& $(0.8)$ & $(0.08)$ & $(-)$ \\
\hline
\end{tabular}

a The number in the first row for each factor represents the correlation coefficient $(r)$ and the number in the second row in parenthesis represents $P$ value.

lipid and other biochemical parameters was examined.

Of 52 patients investigated in this study, $61.5 \%$ were males. The mean age of the patients was $60.48 \pm 17.70$ (range; 13-78) years. The mean dialysis duration in the patients was $44.05 \pm 39.52$ months. In comparison, the mean age of patients in the study of Khatami et al was $57.4 \pm 15.4$ years old with no significant association between serum magnesium level and age (2). The mean age of patients in the study of Robles et al was $52.76 \pm 18.46$ years old and $64 \%$ of their patients were males (6). The results of these studies were similar to those of the present study.

In our study, serum magnesium, triglyceride and cholesterol levels were $2.2 \pm 0.2 \mathrm{mg} / \mathrm{dL}, 98.82 \pm 65.70 \mathrm{mg} /$ 
Table 4. The association of serum magnesium, cholesterol, and triglyceride with other parameters in hemodialysis patients

\begin{tabular}{|c|c|c|c|c|c|c|c|c|c|c|}
\hline & $\begin{array}{c}\text { Parathyroid } \\
\text { hormone } \\
\text { (pg/mL) }\end{array}$ & $\begin{array}{l}\text { Serum } \\
\text { calcium } \\
\text { (mg/dL) }\end{array}$ & $\begin{array}{l}\text { Serum } \\
\text { albumin } \\
\text { (g/dL) }\end{array}$ & $\begin{array}{c}\text { Bicarbonate } \\
\text { (mEq/L) }\end{array}$ & $\begin{array}{c}\text { Alkaline } \\
\text { phosphatase } \\
(\mathrm{U} / \mathrm{L})\end{array}$ & $\begin{array}{c}\text { Serum } \\
\text { phosphorus } \\
\text { (mg/dL) }\end{array}$ & $\begin{array}{c}\text { Vitamin D } \\
\text { (ng/dL) }\end{array}$ & URR (\%) & $\begin{array}{l}\text { Dialysis } \\
\text { duration } \\
\text { (month) }\end{array}$ & $\begin{array}{c}\text { Dialysis } \\
\text { dose }\end{array}$ \\
\hline $\begin{array}{l}\text { Magnesium } \\
(\mathrm{mEq} / \mathrm{L})\end{array}$ & $\begin{array}{c}0.28 \\
(0.04)^{a}\end{array}$ & $\begin{array}{l}0.04 \\
(0.7)\end{array}$ & $\begin{array}{c}0.50 \\
(<0.001)\end{array}$ & $\begin{array}{c}0.17 \\
(0.22)\end{array}$ & $\begin{array}{l}0.01 \\
(0.9)\end{array}$ & $\begin{array}{c}0.14 \\
(0.31)\end{array}$ & $\begin{array}{l}-0.23 \\
(0.10)\end{array}$ & $\begin{array}{c}0.18 \\
(0.20)\end{array}$ & $\begin{array}{c}0.25 \\
(0.06)\end{array}$ & $\begin{array}{c}0.27 \\
(0.04)^{*}\end{array}$ \\
\hline $\begin{array}{l}\text { Cholesterol } \\
(\mathrm{mg} / \mathrm{dL})\end{array}$ & $\begin{array}{r}-0.12 \\
(0.3)\end{array}$ & $\begin{array}{l}-0.16 \\
(0.2)\end{array}$ & $\begin{array}{l}0.04 \\
(0.7)\end{array}$ & $\begin{array}{l}0.02 \\
(0.8)\end{array}$ & $\begin{array}{l}-0.06 \\
(0.6)\end{array}$ & $\begin{array}{l}-0.07 \\
(0.5)\end{array}$ & $\begin{array}{r}-0.02 \\
(0.8)\end{array}$ & $\begin{array}{c}0.004 \\
(0.9)\end{array}$ & $\begin{array}{r}-0.22 \\
(0.1)\end{array}$ & $\begin{array}{r}-0.20 \\
(0.1)\end{array}$ \\
\hline $\begin{array}{l}\text { Triglyceride } \\
\text { (mg/dL) }\end{array}$ & $\begin{array}{l}0.11 \\
(0.4)\end{array}$ & $\begin{array}{l}-0.25 \\
(0.07)\end{array}$ & $\begin{array}{c}0.005 \\
(0.9)\end{array}$ & $\begin{array}{l}-0.12 \\
(0.3)\end{array}$ & $\begin{array}{l}-0.12 \\
(0.3)\end{array}$ & $\begin{array}{l}-0.05 \\
(0.7)\end{array}$ & $\begin{array}{l}0.11 \\
(0.4)\end{array}$ & $\begin{array}{r}-0.03 \\
(0.7)\end{array}$ & $\begin{array}{l}-0.23 \\
(0.08)\end{array}$ & $\begin{array}{l}-0.24 \\
(0.08)\end{array}$ \\
\hline
\end{tabular}

a The number in the first row for each factor represents the correlation coefficient $(r)$ and the number in the second row in parenthesis represents $P$ value.

$\mathrm{dL}$ and $130.42 \pm 42.55 \mathrm{mg} / \mathrm{dL}$, respectively. Verma et al, on the other hand, reported the levels of serum magnesium, triglyceride and cholesterol as $2.3 \pm 0.98,174.1 \pm 44.62$ $\mathrm{mg} / \mathrm{dL}$ and $144.54 \pm 58.09 \mathrm{mg} / \mathrm{dL}$, respectively (13). In the study by Khatami et al, serum magnesium level was $2.8 \pm 0.5 \mathrm{mg} / \mathrm{dL}$ (2). Robles et al categorized hemodialysis patients in terms of cholesterol levels into $<200 \mathrm{mg} / \mathrm{dL}$, $200-250 \mathrm{mg} / \mathrm{dL}$ and $>250 \mathrm{mg} / \mathrm{dL}$ groups and reported the magnesium levels in these groups as $2.0 \pm 0.3 \mathrm{mg} / \mathrm{dL}$, $2.1 \pm 0.2 \mathrm{mg} / \mathrm{dL}$ and $2.4 \pm 0.3 \mathrm{mg} / \mathrm{dL} \mathrm{mg} / \mathrm{dL}$, respectively. Furthermore, serum cholesterol levels were described as $176.6 \pm 19.3 \mathrm{mg} / \mathrm{dL}, 215.8 \pm 11.7 \mathrm{mg} / \mathrm{dL}$ and $289.9 \pm 49.4$ $\mathrm{mg} / \mathrm{dL}$, while serum triglyceride levels were $114.1 \pm 48.8$ $\mathrm{mg} / \mathrm{dL}, \quad 177.4 \pm 74.6 \mathrm{mg} / \mathrm{dL}$ and $225.4 \pm 151.2 \mathrm{mg} / \mathrm{dL}$ in these groups respectively. In accordance with our findings, these results showed a positive and insignificant correlation between serum triglyceride and cholesterol levels in different groups (6). Furthermore, Robles et al showed a positive and significant correlation between serum magnesium and cholesterol levels; however, an inverse and insignificant correlation between these parameters was observed in our study. It is possible that dietary magnesium restriction led to increased serum cholesterol and triglyceride levels suggesting an inverse correlation between magnesium and both cholesterol and triglyceride levels (14-16). In another study, Baradaran et al reported no association between serum lipids and neither parathyroid hormone nor serum calcium in dialysis patients. Although they described an insignificant correlation between serum magnesium and cholesterol levels, a positive and significant relationship was reported between serum magnesium and triglyceride levels. Accordingly, this correlation was attributed to the altered metabolism of triglycerides within liver in the presence of magnesium (17).

As mentioned, we found inverse and non-significant correlations between serum magnesium level and both serum cholesterol and triglyceride levels. Furthermore, a positive and insignificant correlation was observed between cholesterol and triglyceride levels in our study. Khatami et al also reported that serum magnesium levels positively and significantly correlated with serum phosphorus and albumin (2). In the study of Khatami et al, patients with low serum magnesium level had also significantly lower serum albumin and cholesterol levels in comparison with patients who had higher serum magnesium levels. On the other hand, serum magnesium positively and significantly correlated with serum phosphorus level (2). In comparison, serum magnesium showed positive and significant correlations with albumin and parathormone in the present study.

Nasri et al reported a linear correlation between serum magnesium and triglyceride levels in hemodialysis patients (18). In comparison, we here observed inverse and insignificant correlations between serum magnesium with cholesterol and triglyceride levels. In another study, serum magnesium levels were lower, and serum cholesterol and triglyceride levels were higher in diabetic patients than general population indicating an inverse correlation between serum magnesium and serum cholesterol and triglyceride levels, showing a possible role for hypomagnesemia in the pathogenesis of vascular complications in diabetic patients (19). In the study of Verma et al, the association between serum magnesium and total serum cholesterol was insignificant, however, a statistically significant and inverse correlation was recorded between serum magnesium and triglyceride levels (13). Robles et al also suggested that magnesium may participate in the regulation of lipid metabolism in hemodialysis patients (6). It has also been reported that using magnesium salts as phosphate-binding agents can prevent vascular calcification. Furthermore, it has also been reported that parathyroid hormone secretion was inversely correlated with serum magnesium levels (20). Overall, the association between serum magnesium and serum cholesterol and triglyceride is contradictory, and further studies are required to divulge the role of other contributing factors.

\section{Conclusion}

We observed inverse and non-significant correlations between serum magnesium and both serum cholesterol 
and triglyceride levels. On the other hand, serum magnesium significantly correlated with serum albumin and parathormone levels.

\section{Limitations of the study}

Our sample size was relatively low, limiting the power of our study. Therefore, more multicentric studies on larger populations are recommended to validate the repeatability of our results.

\section{Authors' contribution}

SM, LHZ and MF conducted the research. AM conducted the statistical analysis. MF prepared the primary draft. SM revised and prepared the final manuscript. All authors read and approved the final paper.

\section{Conflicts of interest}

The authors declare no conflicts of interest.

\section{Ethical considerations}

Ethical issues (including plagiarism, misconduct, data fabrication, falsification, double publication or submission, redundancy) have been completely observed by the authors.

\section{Funding/Support}

This study was extracted from the M.D, thesis of Milad Fooladgar at this University (proposal\# 2012 and thesis \#1293), supported by Shahrekord University of Medical Sciences, Shahrekord, Iran.

\section{References}

1. Collins AJ, Li S, Ma JZ, Herzog C. Cardiovascular disease in end-stage renal disease patients. Am J Kidney Dis. 2001;38:26-9. doi: 10.1053/ajkd.2001.27392.

2. Khatami MR, Mirchi E, Khazaeipour Z, Abdollahi A, Jahanmardi A. Association between serum magnesium and risk factors of cardiovascular disease in hemodialysis patients. Iran J Kidney Dis. 2013;7:47.

3. Lindner A, Charra B, Sherrard DJ, Scribner BH. Accelerated atherosclerosis in prolonged maintenance hemodialysis. $\mathrm{N}$ Engl J Med. 1974;290:697-701.

4. Ma KW, Greene EL, Raij L. Cardiovascular risk factors in chronic renal failure and hemodialysis populations. Am J Kidney Dis. 1992;19:505-13. doi: 10.1016/s02726386(12)80827-4.

5. Appel G. Lipid abnormalities in renal disease. Kidney Int. 1991;39:169-83.

6. Robles N, Albarran L, Espada R. Correlation of serum magnesium and serum lipid levels in hemodialysis patients. Nephron. 1998; 78:118-9. doi: 10.1159/000044895.
7. Ford ES. Serum magnesium and ischaemic heart disease: findings from a national sample of US adults. Int J Epidemiol. 1999;28:645-51. doi: 10.1093/ije/28.4.645.

8. Gartside P, Glueck C. The important role of modifiable dietary and behavioral characteristics in the causation and prevention of coronary heart disease hospitalization and mortality: the prospective NHANES I follow-up study. J Am Coll Nutr. 1995;14:71-9. doi: 10.1080/07315724.1995.10718476.

9. Liao F, Folsom AR, Brancati FL. Is low magnesium concentration a risk factor for coronary heart disease? The Atherosclerosis Risk in Communities (ARIC) Study. Am Heart J. 1998;136:480-90. doi: 10.1016/s00028703(98)70224-8.

10. Andress DL, Maloney NA, Coburn JW, Endres DB, Sherrard DJ. Osteomalacia and aplastic bone disease in aluminumrelated osteodystrophy. J Clin Endocrinol Metab. 1987; 65:11-6. doi: 10.1210/jcem-65-1-11.

11. Moe SM, Drüeke TB. Management of secondary hyperparathyroidism: the importance and the challenge of controlling parathyroid hormone levels without elevating calcium, phosphorus, and calcium-phosphorus product. Am J Nephrol. 2003;23:369-79. doi: 10.1159/000073945.

12. Sepehri Z, Darvishi M, Kiani Z, Sargazi A, Bagheri G, Aali $\mathrm{H}$, et al. Prevalence of renal osteodystrophy in hemodialysis patients in imam Khomeini hospital in Zabul. J Zabol Univ Med Sci Health Serv. 2013;5:9-15.

13. Verma $D$, Chahande $S$. Correlation of serum magnesium with lipid profile in CKD patients on maintenance hemodialysis. Int J Sci Res. 2016;5:1798-81.

14. Rayssiguier Y, Gueux E, Weiser D. Effect of magnesium deficiency on lipid metabolism in rats fed a high carbohydrate diet. J Nutr. 1981;111:1876-83. doi: 10.1093/ jn/111.11.1876.

15. Inagaki $\mathrm{O}$, Shono $\mathrm{T}$, Nakagawa $\mathrm{K}$, Gomikawa $\mathrm{S}$, Mori H, Fujita Y. Effect of magnesium deficiency on lipid metabolism in uremic rats. Nephron. 1990;55:176-80. doi: $10.1159 / 000185948$.

16. Vitale JJ, Velez H, Guzman C, Correa P. Magnesium deficiency in the Cebus monkey. Circ Res. 1963;12:642-50. doi: 10.1161/01.res.12.6.642.

17. Baradaran A, Nasri H. Correlation of serum magnesium with dyslipidemia in maintenance hemodialysis patients. Indian J Nephrol. 2004;14:46.

18. Nasri H, Kheiri S. Effects of diabetes mellitus, age, and duration of dialysis on parathormone in chronic hemodialysis patients. Saudi J Kidney Dis Transpl. 2008;19:60831-.

19. Khubchandani AS, Sanghani H. Study of serum magnesium and $\mathrm{HbA} 1 \mathrm{C}$ in diabetic patients along with changes in their lipid profiles. Int J Clin Pract. 2013;23:717-9.

20. Tzanakis IP, Oreopoulos DG. Beneficial effects of magnesium in chronic renal failure: a foe no longer. Int Urol Nephrol. 2009;41:363-71.

Copyright $\odot 2020$ The Author(s); Published by Published by Society of Diabetic Nephropathy Prevention. This is an open-access article distributed under the terms of the Creative Commons Attribution License (http://creativecommons.org/licenses/by/4.0), which permits unrestricted use, distribution, and reproduction in any medium, provided the original work is properly cited. 